\title{
THE EFFECT OF SECTORAL DIVISION ON GDP PER CAPITA IN THE SLOVAK REPUBLIC
}

\section{Peter Burger', Lea Šlampiaková2}

1 Technical University of Košice, Faculty of Economics, Department of Regional Science and Management, Slovakia, ORCID: 0000-0002-7512-4660,Peter.Burger@tuke.sk;

2 Matej Bel University in Banská Bystrica, Faculty of Economics, Department of Finance and Accounting, Slovakia, ORCID: 0000-0001-8995-8781, lea.slampiakova@umb.sk.

\begin{abstract}
The paper aims to analyse the sectoral division of the national economy in the Slovak Republic from various points of view. The authors examine the developmental changes in the number of people employed in different economic sectors (primary, secondary, tertiary, and quaternary) from 1948 to 2018 reflecting the natural development of the economy over that time. In order to do this, they have used a logical and comparative study of theoretical knowledge in accordance with the analysis of empirical data. The descriptive statistics are based on a sample of aggregate data about sectoral division in the Slovak Republic for the period 1948-2018. A cluster analysis on the data of sectoral division in all EU member states in 2010 and in 2017 was carried out in order to obtain a basic overview and opportunity to compare. The main focus of this paper is to examine the impact of sectoral division of the national economy on the Slovak Republic's real GDP per capita. The research is based on panel regression as well as Granger causality tests on a sample of all 8 Slovak regions between 2001 and 2018. The results of the Granger causality tests show that causality runs one-way from all four sectors to real GDP per capita. Based on this, it is appropriate to carry out panel regression analysis. The results of this analysis suggest that all given sectors in period $t-1$ have had a significant impact on GDP per capita. In particular, the primary and secondary sectors have both had a relatively significant negative impact while the tertiary and quaternary sectors have had a positive one. It is interesting that the tertiary sector has had a greater positive impact than the quaternary one in the Slovak Republic.
\end{abstract}

Keywords: Sectoral division, economic performance, quaternary economy, employment trends.

JEL Classification: J21, O11, 014.

APA Style Citation: Burger, P., \& Šlampiaková, L. (2021). The Effect of Sectoral Division on GDP per Capita in the Slovak Republic. E\&M Economics and Management, 24(1), 21-37. https://doi.org/10.15240/tul/001/2021-1-002

\section{Introduction}

The presumption that the production structure of an economy is the fundamental determinant of economic performance has been confirmed by previous economic literature. There is growth observed in a country when the production structure is composed of commodities with intense returns (Reinert, 2008; Andreoni \& Scazzieri, 2014). Moreover, Andreoni (2014) has noted that the proximate source of innovation is a further source of importance in economic activities with increasing returns.
According to Fourastié (1951), sectors are developing along with technological and innovation developments, but not evenly. In the sectoral structure of the national economy of the Slovak Republic, the main focus had been initially on agriculture, fishing and mining, until the industrialisation process began. In 1961, a turning point came when the number of people employed in the secondary sector exceeded that in the primary one. Delays in the industrial phase in Slovakia were also caused by economic crises, wars, and political 
upheavals. The main aspect of the late and inefficient industrialisation process was a poorly adjusted industrial structure until 1989, when the dominant industries were very energy intensive. Major deficiencies stemmed from the type of ownership (state-owned enterprises), which did not allow innovation to the same extent as in other countries.

A significant growth of the services sector in Slovakia can only be observed after 1989, at the beginning of private business activities. According to Korec (2007), not only processes connected with the change of the centrally planned economy into a market economy, but also processes connected with globalisation or processes connected with the onset of the postindustrial period have a significant impact on changes in the sectoral structure of Slovakia's economy. The post-communist transformation process after 1989 is characterised by a decrease in the importance of industry in the economy and an increase in the importance of activities in the tertiary and quaternary sectors. At the same time, the dominance of metropolitan regions is increasing, thereby increasing disparities between the regions.

A significant increase in the tertiary sector during the $20^{\text {th }}$ century in the world as well as the tendency to put importance on knowledge, technology, and innovation has led to extending the traditional range of economic sectors through a quaternary sector. The quaternary sector and its share of the total sectoral structure of the economy requires a highly skilled and educated labour and ability of the economy to effectively use the human, social and intellectual capital. "For this reason, it is possible to assume its higher representation in highly developed countries and eventually its growing importance over time and towards the future. An integral property of the quaternary sector is that, directly or indirectly, intentionally or unintentionally, immediately or with delay it will certainly affect the existing sectoral structure and productivity in all spheres of economic activities" (Kenessey, 1987, p. 383).

\section{Literature Review}

The national economy is the interconnection of interrelated macroeconomic elements that are categorised into several specific sectors/ industries by type of their economic activities. Accordingly, we also distinguish the basic industries applied in the Slovak economy. The structure of the national economy is based on consumer demand, which means that according to the proposed framework the industries are divided into three or four basic sectors.

Melišek defines the formation of the sector as a combination of economic sectors with similar characters. According to him (2008, p. 184), "inclusion in a particular sector is carried primarily by the criterion indicator of labour productivity, specifically under objective conditions of labour productivity growth of individual sectors and through the impact of these sectors on the productivity of the national economy". According to him, the criteria for qualifying in a particular sector have not been universally agreed. Therefore, the definitions of the sectors use different criteria such as: promoting technological progress, relationships in the production process between factors of production, natural conditions, labour productivity, different employment, changes in the composition of demand, the relationship of different activities in meeting the final objective.

The primary sector, as stated by Turečková (2012), includes those economic activities that are fundamental and primary in nature and are closest to human development. Such activities include agriculture and livestock breeding, beekeeping, fruit pickling, fishing, hunting and forestry, pasturage, logging, quarrying and mining. Despite their important role in human life, their economic importance has been declining in recent decades and centuries, like the share of the primary sector in GDP and the employment of the population in the primary sector. It is typical for the primary sector that it has a larger share of employed people than the share of its contribution to GDP. Stehel et al. (2019) state that technical efficiency also often becomes the cause of stagnation of the primary sector and its individual branches at present. The result is then a low level of labour productivity in the primary sector.

Hudcovský (2013) states that a direct comparison of the western countries and the V4 countries shows that the primary sector production in the V4 countries accounts for a higher share of a country's GDP than in the western countries. However, employment (with the exception of Poland) is at approximately similar levels. Production in the western countries is more labour intensive, which allows absorbing workers who would succeed on the labour market with great difficulty. For example, 
in Austria almost $60 \%$ of all people employed in the primary sector have only lower secondary education or less.

Activities which are included in the secondary sector are directly related to the transformation of raw material and semifinished products into finished products. Generally, it is a process of manufacture, processing, assembly, and construction. Specifically, it includes metalworking and the metallurgical industry, the automotive industry, the manufacture of trains, aircraft and ships, the textile and chemical industries, the mechanical engineering, the food industry, the construction industry, the power distribution industry, the pharmaceutical industry, and many others. According to Hudcovský (2013), the share of the secondary sector in GDP has been declining with the economic development of the country. When comparing the developed western economies to the V4 countries, the developed economies have a significantly lower share of the secondary sector in GDP, which is in line with the real convergence patterns. This relative decline is mainly due to the expansion of the tertiary and quaternary sectors, which in relative terms reduces the size of the industrial and construction sectors. Comparing the sector's share of GDP and employment, it can be concluded that this sector is capital intensive and is characterised by a higher productivity rate with a lower labour force involvement.

The tertiary sector of the economy includes all economic activities of an intangible nature, i.e. services intended for households, companies and the state to satisfy both individual and collective needs. It consists in providing services such as retail trade, wholesale trade, transportation, distribution, tourism and accommodation, catering, cultural, entertainment and recreational activities, public administration, and defence activities (Turečková, 2012).

According to Kenessey (1987), it was the development of technology and the growing significance of the acquired knowledge and skills of human capital as well as the focus of companies on research and development that gave rise to the quaternary sector - the so-called knowledge sector. Mateides and Ďad'o (2002) point out that the science and public sector services have been moved from the tertiary sector to the quaternary sector. This includes health care, education, research and science, and activities which will have the largest growth rate in the future. The quaternary sector is a reflection of the knowledge-based economy. It is this knowledge-based economy which is a significant source of competitive advantage in all areas of the economy and the economy as a whole. Knowledge-based activities are an important source of national and regional competitiveness. In European Union countries, the knowledge industries represent not only one of the fastest growing sources of new jobs, but also account for an increasing share of gross value added and exports (Melachroinos \& Spence, 2013). Yun (2015) argues that the purpose of the quaternary sector should also be to conquer the growth limits of capitalism. Cooke et al. (2019) define the quaternary economy as the knowledge-based part of the economy which typically includes services such as information technology, information generation and sharing, media, research and development, as well as knowledge-based services.

The share of the quaternary sector on the total sectoral structure of the economy requires a high level of skilled and educated labour and the ability of the economy to use this human and intellectual capital effectively. Segal (2011) describes the quaternary sector boom very accurately in that being in only a few places - especially in the form of advanced, innovative 'cluster-platforms' - but being massively profitable means that they can service global demand through the outsourcing and 'open innovation' business models each in comparable ways.

According to Constantine (2017), it is a country's economic structure that is the fundamental cause of economic performance. Therefore, differences in economic structures across time and space can explain the differences in economic development. A country has an increasing returns productive structure if it produces high value added commodities that are technically sophisticated and the reverse holds - a decreasing returns economic structure is composed of low value added commodities that are technologically simple. Fundamentally, economic activities reflect an economy's productive capabilities and a country's productive structure is simply the aggregate representation of its technological capabilities. The empirical evidence of economic effects and concrete aspects of the 
quaternary economy was provided by Cooke et al. (2019). The areas where the quaternary sector has the spatial power of "digital empires" in their reach, scope and variety across large swathes of the global economy are Silicon Valley in the USA, Cambridge area in the UK and Bay Area News groups in Israel. The expansion of the quaternary sector is therefore mainly in such a "cluster-platforms" way which was defined by Segal (2011).

\section{Research Methodology}

An indicator of the average number of people employed in each sector over the period considered was used to assess the impact of individual sectors on GDP. The average number of people employed was reported by enterprises depending on their legal obligation in classifying enterprises into size groups. Until 2009 , the statistics took only into account data from statistical reports submitted by enterprises with more than 20 employees. After that year, data for all enterprises have been included. Also, employees of the Armed Forces were not part of statistical surveys until 2006. In 2007, the Slovak Republic issued the Decree of the Statistical Office of the Slovak Republic of 18 June 2007 issuing the Statistical classification of economic activities, which entered into force on 1 January 2008. The Decree changes the Statistical branch classification of economic activities (OKEČ), in force until then, for the Statistical classification of economic activities (SK NACE Rev. 2), which is still in force in the European Union countries, including Slovakia (SLOV-LEX, 2007).

In order to establish a uniform classification in the statistical collection and comparison of data not only within the European Union, but also in a wider geographical context, the creation of "NACE Rev. 2 - Statistical classification of economic activities in the European Community" was an important milestone (European Communities, 2008). The framework of NACE Rev. 2 provides space for presenting the same methodology in collecting a huge quantity of data on economic activities in the field of economic statistics, such as production or employment. In 1991-2008, the division of economic activities according to the Branch classification of economic activities (OKEČ) was in force in the Slovak Republic. In accordance with European regulations, NACE Rev. 2 classification entered into force in
2008 and is still in force. A detailed analysis of economic activities, including a comparison of economic sectors in which they are classified, are provided in the classification proposed by Bell (1976), European Commission (2008), Turečková and Martinát (2015), shown in Tab. 1.

The paper aims to examine the sectoral division of a national economy and its impact on a country's real GDP. The partial aim is to assess whether the impact of the quaternary sector on a country's GDP remains positive even if the country is less innovative and therefore its ability to transform knowledge into economic performance is questionable, such as Slovakia. In the case of Slovakia, the impact of the quaternary sector is also questionable due to the fact that the majority of the population is employed in the secondary and tertiary sectors. The results of the analysis have the potential to provide valuable information for economic policy makers in the optimum targeting of state aid.

The analysis uses secondary data:

- data about GDP per capita in the Slovak Republic obtained from the databases of the Statistical Office of the Slovak Republic "DATAcube";

- data about GDP per capita in EU countries obtained from the Eurostat archives;

- data about the sectoral division in the Slovak Republic obtained from the archives of the Statistical Office of the Slovak Republic;

- data about the sectoral division of other EU countries obtained from national accounts employment data by industry obtained from the Eurostat archives.

An analysis of these data has been carried out using various methods such as descriptive statistics, cluster analysis, panel regression, and a Granger causality test. The descriptive statistics have been done on a sample of aggregate data about the sectoral division of the whole Slovak Republic territory between 1948 and 2018 (the data of the individual regions have been aggregated in order to achieve their higher illustrative clarity). This demonstrates the development of the sectoral divisions over time. A cluster analysis was carried out on the data of the sectoral divisions from all EU member states in 2010 and 2017.

Data clustering is a technique which involves the division of the original data set into multiple subsets (clusters) in such a way that 


\section{Tab. 1: Comparative scheme of industrial models and their sectors}

\begin{tabular}{|c|c|c|c|c|}
\hline $\begin{array}{l}\text { Economic } \\
\text { sector }\end{array}$ & Primary & Secondary & Tertiary & Quaternary \\
\hline $\begin{array}{l}\text { Mode of } \\
\text { production }\end{array}$ & Extractive & Fabrication & \multicolumn{2}{|c|}{ Processing, recycling } \\
\hline Technology & Craft & Machine technology & \multicolumn{2}{|c|}{ Intellectual technology } \\
\hline Methodology & Trial and error & Experimentation & \multicolumn{2}{|c|}{ Simulations, models, decision theory } \\
\hline $\begin{array}{c}\text { Time } \\
\text { perspective }\end{array}$ & $\begin{array}{c}\text { Orientation to the } \\
\text { past }\end{array}$ & $\begin{array}{c}\text { Ad hoc } \\
\text { adaptiveness }\end{array}$ & \multicolumn{2}{|c|}{$\begin{array}{c}\text { Future orientation - forecasting and } \\
\text { planning }\end{array}$} \\
\hline $\begin{array}{c}\text { Detailed } \\
\text { theoretical } \\
\text { classification }\end{array}$ & $\begin{array}{l}\text { - Agriculture; } \\
\text { - Forestry; } \\
\text { - Fishing; } \\
\text { - Mining and } \\
\text { quarrying }\end{array}$ & $\begin{array}{l}\text { - Manufacturing; } \\
\text { - Processing of raw } \\
\text { materials; } \\
\text { - Construction }\end{array}$ & $\begin{array}{c}\text { - All services, } \\
\text { excluding services } \\
\text { related to the } \\
\text { creation and sharing } \\
\text { of knowledge and } \\
\text { information }\end{array}$ & $\begin{array}{l}\text { - Services related } \\
\text { to the creation } \\
\text { and sharing of } \\
\text { knowledge and } \\
\text { information }\end{array}$ \\
\hline $\begin{array}{c}\text { Industry } \\
\text { according } \\
\text { to NACE Rev. } 2\end{array}$ & $\begin{array}{l}\text { Section A - } \\
\text { Agriculture, } \\
\text { forestry and } \\
\text { fishing; } \\
\text { Section B - } \\
\text { Mining and } \\
\text { quarrying. }\end{array}$ & $\begin{array}{c}\text { Section C- } \\
\text { Manufacturing; } \\
\text { Section D- } \\
\text { Electricity, gas, } \\
\text { steam and air } \\
\text { conditioning supply; } \\
\text { Section E - Water } \\
\text { supply, sewerage, } \\
\text { waste management } \\
\text { and remediation } \\
\text { activities; } \\
\text { Section F- } \\
\text { Construction }\end{array}$ & \begin{tabular}{|c|} 
Section $G$ - \\
Wholesale and \\
retail trade, etc; \\
Section H - \\
Transportation and \\
storage; \\
Section I- \\
Accommodation \\
and food service \\
activities; \\
Section L- Real \\
estate activities; \\
Section O - Public \\
administration and \\
defence etc; \\
Section $R-$ Arts, \\
entertainment and \\
recreation; \\
Section S - Other \\
service activities; \\
Section T - \\
Activities of \\
households as \\
employers; \\
Section U - \\
Activities of \\
extraterritorial \\
organisations and \\
bodies
\end{tabular} & $\begin{array}{c}\text { Section } \mathrm{J}- \\
\text { Information and } \\
\text { communication; } \\
\text { Section } \mathrm{K}- \\
\text { Financial and } \\
\text { insurance activities; } \\
\text { Section } \mathrm{M} \text { - } \\
\text { Professional, } \\
\text { scientific and } \\
\text { technical activities; } \\
\text { Section } \mathrm{N} \text { - } \\
\text { Administrative and } \\
\text { support service } \\
\text { activities; } \\
\text { Section } \mathrm{P}- \\
\text { Education; } \\
\text { Section Q - Human } \\
\text { health and social } \\
\text { work activities }\end{array}$ \\
\hline
\end{tabular}

Source: own based on Bell (1976), European Commission (2008), Turečková and Martinát (2015) 
the data in each subset have several common characteristics (Abonyi \& Feil, 2007). The cluster analyses were done using Ward linkage, which is a method mostly used to evaluate the distance between clusters. Cluster membership is estimated by calculating the total sum of squared deviations from the mean of a cluster.

The regression analyses were carried out on the panel data. In particular, on the sample of all 8 Slovak regions between 2001 and 2018. The nominal GDP per capita is calculated by using the prices that are current in the given year, therefore it is strongly influenced by inflation. For comparison between one time period and the next it is necessary to convert nominal GDP to real GDP. That process requires dividing the rise in nominal quantities into a real component and an inflation component, through the use of an appropriate price index. The overall GDP price deflator uses components based on the Consumer Price Index (CPI) and the Producer Price Index (PPI) (Feldstein, 2017). The input data of the real GDP per capita in individual regions were obtained by adjusting the nominal GDP using the GDP price deflator based on data from the databases of the Statistical Office of the Slovak Republic "DATAcube". The input data of independent variables were absolute values of people employed in the given sectors of the national economy. The input data were log transformed to achieve a normal distribution of the data.

At first, the Granger causality hypothesis was used to study the causality between the data sets. The GC measure is based on the relative change in the model error when new time series are added to improve the prediction of the dependent signal (Granger, 1969). The panel regression analysis is based on the least squares method in combination with the fixed effects model of cross-sectional data. The fixed effects model was chosen based on Clark and Linzer (2015, p. 30) study: "When variation in the independent variable is primarily within units - that is, the units are relatively similar to one another on average - the choice of random versus fixed effects only matters at extremely high levels of correlation between the independent variable and the unit effects, and when there are very few observations per unit (perhaps less than five, on average). With larger amounts of data - many units and/or observations - there is no discernible difference in estimates of $\beta$ between the two estimators, even when the regressor and the unit effects are very highly correlated. Thus, under these conditions, the appropriate model should be guided by the researcher's goals". Furthermore, Green and Tukey (1960, p. 131) stated: "When a sample exhausts the population, the corresponding variable is fixed, when the sample is a small (i.e., negligible) part of the population the corresponding variable is random". Similarly, Clark and Linzer (2015) added that in any particular dataset, the random effects model will tend to produce better estimates of $\beta$ when there are few units or observations per unit, and when the correlation between the independent variable and unit effects is relatively low. Otherwise, the fixed effects model may be preferable because the random effects model does not induce sufficiently high variance reduction to offset its increase in bias. Based on our data sample and model goals we chose fixed effects.

\section{Research Results and Discussion}

The changes in the position and importance of the sectors of a national economy as well as the number of people employed in them changed very significantly in both Slovakia and the European Union countries in the period considered. The impact of a growth or decline in employment in each of the four sectors of the national economy has a significant impact on GDP per capita in Slovakia.

\subsection{Analysis of Sectoral Development in Slovakia}

The situation in Slovakia in the period considered - from 1948 to 2018, with the exception of 1985-1990, where the data are missing, is shown in Fig. 1. The data from 1948-1984 for the Slovak Socialist Republic (the analysis was carried out separately for the territory of Slovakia) have been taken from a publication issued on the occasion of the $40^{\text {th }}$ anniversary of the liberation of Czechoslovakia (Mička et al., 1985). The statistical data from 1985-1990 are not available in the necessary structure. The following data since 1991 have been taken from the Statistical Yearbooks of the Slovak Republic (Statistical Office of the Slovak Republic, 1991-2018).

Over the past seventy years, there have been many developmental changes in the number of people employed which reflect the natural development of the economy. The cross- 


\section{Fig. 1: Analysis of sectoral development by number of employees in the national economy of the Slovak Republic in 1948-2018}

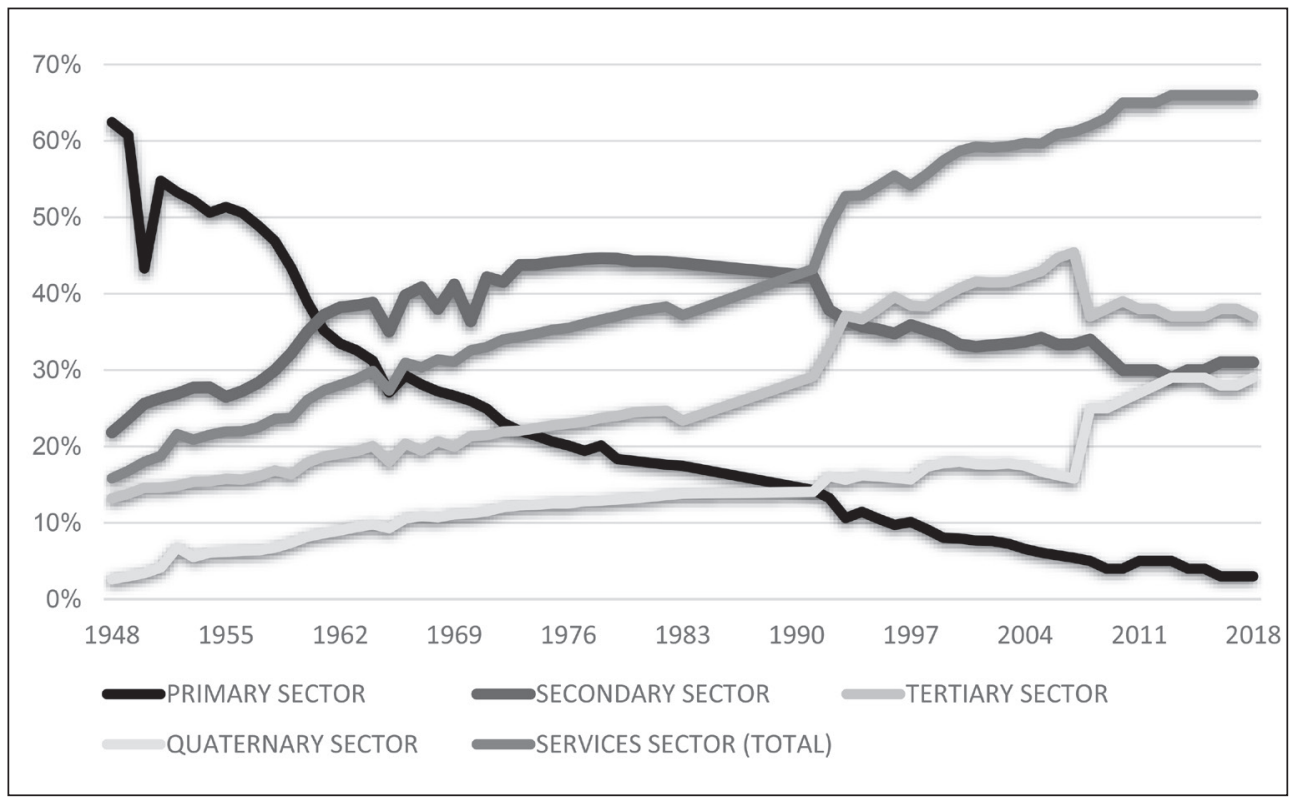

Source: own based on data from the Statistical Office of the Slovak Republic

sectoral fluctuation is a natural phenomenon; according to Fourastié (1951), because of technological advances and changes employees are moving from the primary sector to the secondary sector, and then to the tertiary and quaternary sectors. Fig. 1 shows that at the beginning of the period considered, in 1948, the quaternary sector had very low values, with only $3 \%$ of people employed in science, research and development, education, health, social care, or financial intermediation. At present, it ranks third, just behind the secondary sector.

\subsection{Analysis of the Number of People Employed in Individual Sectors in the European Union Countries}

When analysing the EU countries based on sectoral division of the national economy and GDP per capita, it can be seen that countries with a much higher share of people employed in the primary sector - Romania (33.24\% in 2010 and $24.2 \%$ in 2017 ) and Bulgaria $(20.47 \%$ in 2010 and $19.5 \%$ in 2017) - are the countries with the lowest GDP per capita in the EU.
As regards the share of people employed in the secondary sector, only two countries have this share above $30 \%$ during both years considered: the Czech Republic $35.87 \%$ in 2010 and $36 \%$ in 2017) and Slovakia (31.71\% in 2010 and $31.2 \%$ in 2017). In 2017, the Czech Republic was the only country in the EU where the secondary sector employed most people of all the four sectors. Hedvičáková and Král (2019) also draw attention to a long-term stable and relatively high share of the secondary sector in total employment as well as in the gross value added of the national economy in the Czech Republic during the past 20 years. At the same time, these two countries with a strong secondary sector were below the EU average in terms of performance measured as GDP per capita in both years - 2010 and 2017.

A very high number of people employed in the tertiary sector (more than 45\%) was predominantly in countries with significant profits from tourism (Cyprus - 50.48\% in 2010 and $50.3 \%$ in 2017 , Greece $-48.16 \%$ in 2010 and $49.4 \%$ in 2017 , and Spain $-46.3 \%$ in 


\section{Economics}

2010 and $47.8 \%$ in 2017), but their GDP per capita is below the EU average. Conversely, countries with the highest number of people employed in the quaternary sector (more than $45 \%$ in at least one of the years considered), such as the Netherlands $(46.92 \%$ in 2010 and $48.4 \%$ in 2017 ), Luxembourg $(43.33 \%$ in 2010 and $46.8 \%$ in 2017 ), Belgium (42.43\% in 2010 and $46.4 \%$ in $2017 \%$ ), and Sweden (43.89\% in 2010 and $45.6 \%$ in 2017), had also GDP per capita well above the EU average. In the Czech Republic and Slovakia, the secondary sector is more dominant and the quaternary sector is partially subdued when compared to the EU average. Also, GDP per capita in the Czech Republic and in Slovakia is significantly lower than the EU average.
Based on these data, we carried out a cluster analysis. The first dendrogram (Fig. 2) shows clusters of countries similar to each other based on our input variables in 2010. In order to validate the cluster consistency, we used Silhouette coefficient. According to the results, it is appropriate to divide the EU member states into four clusters.

The first cluster is the larger one, and consists of Austria, Germany, Malta, Ireland, Luxembourg, Sweden, Finland, Denmark, the United Kingdom, Belgium, France, and the Netherlands. These countries have the highest GDP per capita on average $(€ 37,568)$, as well as the highest average share of people employed in the quaternary sector $(40.11 \%)$. On the contrary, these countries also have the

division of the national economy and Real GDP per capita in 2010

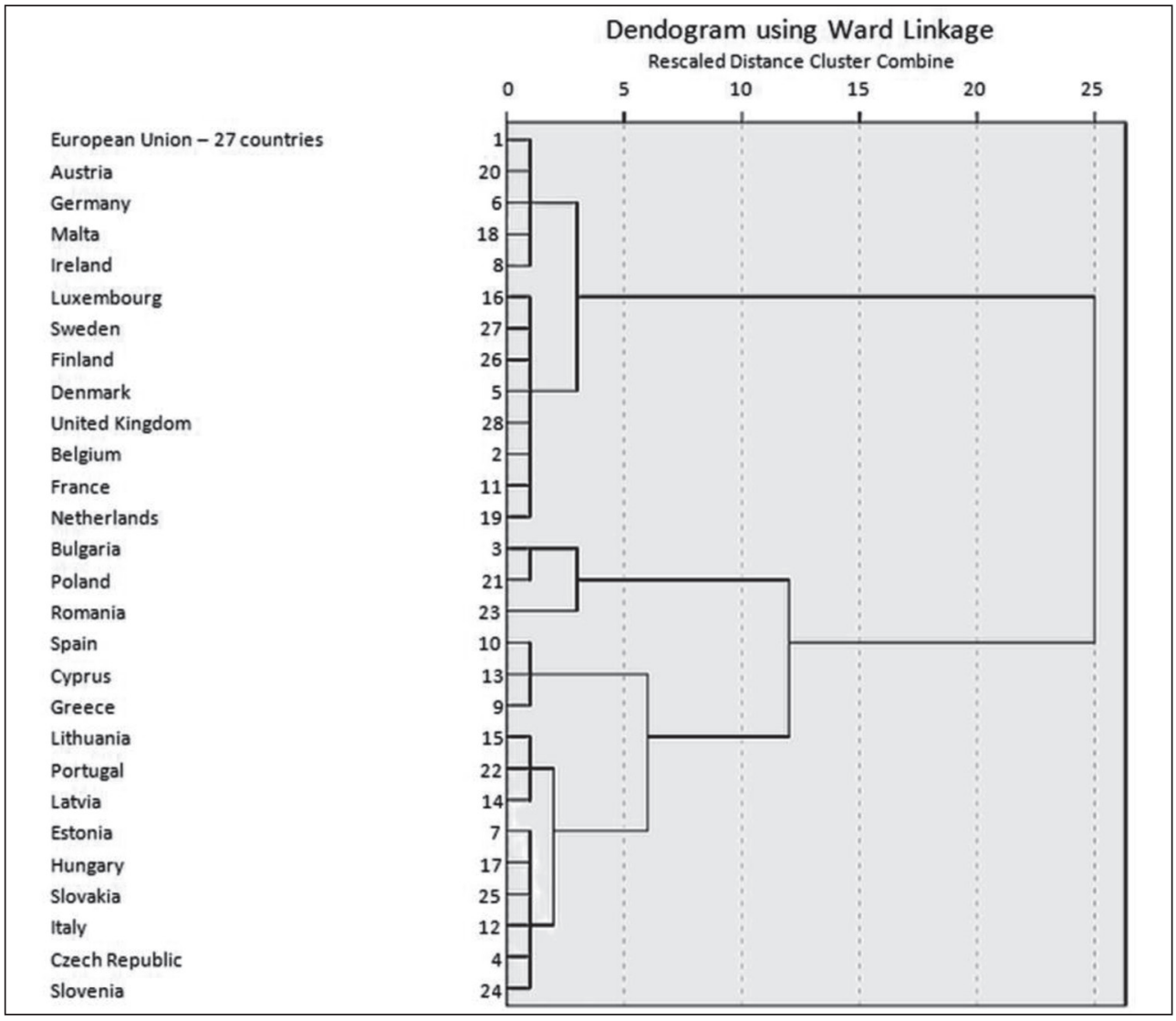

Source: own in SPSS, based on data from Eurostat (2019a, b) 


\begin{tabular}{|c|c|c|c|c|c|}
\hline $\begin{array}{l}\text { Clusters } \\
\text { of countries }\end{array}$ & $\begin{array}{c}\text { Share } \\
\text { of people } \\
\text { employed in } \\
\text { the primary } \\
\text { sector in } \%\end{array}$ & $\begin{array}{l}\text { Share } \\
\text { of people } \\
\text { employed } \\
\text { in the } \\
\text { secondary } \\
\text { sector } \\
\text { in } \%\end{array}$ & $\begin{array}{c}\text { Share } \\
\text { of people } \\
\text { employed } \\
\text { in the tertiary } \\
\text { sector in } \%\end{array}$ & $\begin{array}{l}\text { Share } \\
\text { of people } \\
\text { employed } \\
\text { in the } \\
\text { quaternary } \\
\text { sector } \\
\text { in } \%\end{array}$ & $\begin{array}{l}\text { Real Gross } \\
\text { domestic } \\
\text { product per } \\
\text { capita in } €\end{array}$ \\
\hline $\begin{array}{l}\text { European Union } \\
-27 \text { countries }\end{array}$ & 5.72 & 22.52 & 38.28 & 33.48 & 25,500 \\
\hline First cluster & 2.88 & 19.78 & 37.23 & 40.11 & 37,568 \\
\hline Second cluster & 22.73 & 26.99 & 31.4 & 18.88 & 6,877 \\
\hline Third cluster & 6.76 & 19.47 & 48.32 & 25.46 & 22,253 \\
\hline Fourth cluster & 6.5 & 28.23 & 38.12 & 27.15 & 14,201 \\
\hline
\end{tabular}

Source: own based on data from Eurostat (2019a, b)

lowest average share of people employed in the primary sector $(2.88 \%)$.

The second cluster consists of Bulgaria, Poland, and Romania. The GDP per capita in these countries is the lowest and significantly below the EU average $(€ 6,877)$. These countries have also the lowest share of people employed in the quaternary sector $(18.88 \%)$ and a very significant primary sector compared to other clusters $(22.73 \%)$.

The third cluster consists of Spain, Cyprus, and Greece. These countries have a significantly predominant tertiary sector $(48.32 \%)$, benefiting mainly from tourism. Their average GDP per capita $(€ 22,253)$ is slightly below the EU average.

The fourth cluster consists of Lithuania, Portugal, Latvia, Estonia, Hungary, Slovakia, Italy, the Czech Republic, and Slovenia. The majority of the population in these countries is also employed in the tertiary sector (38.12\%), but the secondary $(28.23 \%)$ and quaternary $(27.15 \%)$ sectors are also important. The share of people employed in the secondary sector is higher than the EU average $(22.52 \%)$ and also higher than in the other three clusters. The average GDP per capita is significantly lower than the EU 27 average in $2010(€ 14,201)$.

The average values of the share of people employed in individual sectors for the European Union as a whole as well as for each cluster individually, including real GDP per capita within individual clusters, are shown in Tab. 2.

The second dendrogram (Fig. 3) illustrates clusters of countries with a similar real GDP per capita and sectoral structure of their national economies in 2017. Similarly, as in 2010, based on the results of Silhouette coefficient it is appropriate to divide the EU member states into four clusters.

The first cluster is larger, consisting of Denmark, France, the United Kingdom, Ireland, Malta, Belgium, Luxembourg, Sweden, the Netherlands, Germany, Finland, Austria, and Italy. On average, these countries have the highest real GDP per capita $(€ 40,355)$, as well as the highest average share of people employed in the quaternary sector $(41.55 \%)$. The second most important sector is tertiary with an average of $36.94 \%$ of people employed. The country which has changed its position compared to 2010 is Italy, which moved from the fourth cluster to that one.

The second cluster consists of Spain, Cyprus, and Greece - countries with the predominant tertiary sector $(49.17 \%)$, benefiting mostly from tourism. These countries, in the same composition, were part of cluster 3 in 2010. Their average GDP per capita is still relatively high $(€ 21,647)$, but lower than the EU average. Interestingly, while real GDP per capita in the EU countries increased - in line 


\section{Economics}

with expectations - between 2010 and 2017, real GDP per capita in this cluster declined over the period considered. The main reason is Greece's economic problems, which were also reflected in the indicator investigated by us. The composition of this cluster of countries has not changed compared to 2010.

However, the third cluster now consists of only two countries: Bulgaria and Romania. Poland moved from that cluster in 2010 to the one which includes the other V4 countries. The sectoral division of their national economies is very balanced. Compared to other clusters of countries, the primary sector is very significant here $(21.85 \%$ on average). The GDP per capita is the lowest $(€ 7,315)$.
The fourth cluster consists of Croatia, Lithuania, Latvia, Portugal, Poland, Slovenia, Estonia, Hungary, Slovakia, and the Czech Republic. They are countries that - with the exception of Portugal - acceded to the EU after 2000. Croatia was not included in the dendrogram for 2010 because this country acceded to the EU in as late as 2013. While the majority of the population in these countries is employed in the tertiary sector, too $(37.21 \%)$, it is slightly less than the EU average (38.1\%) in the tertiary sector. It seems that the secondary $(27.80 \%)$ and quaternary $(28.32 \%)$ sectors are also very significant ones. The average real GDP per capita is $€ 14,361$, which is significantly less than the EU average.

\section{Fig. 3: Dendrogram of groups of European Union countries based on the sectoral division of the national economy and Real GDP per capita in 2017}

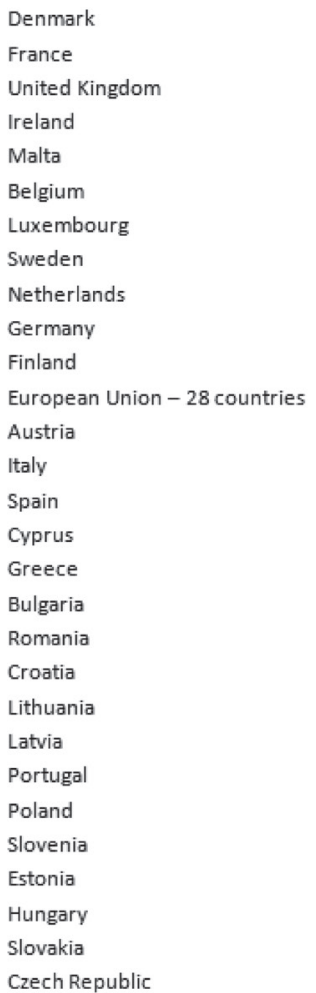

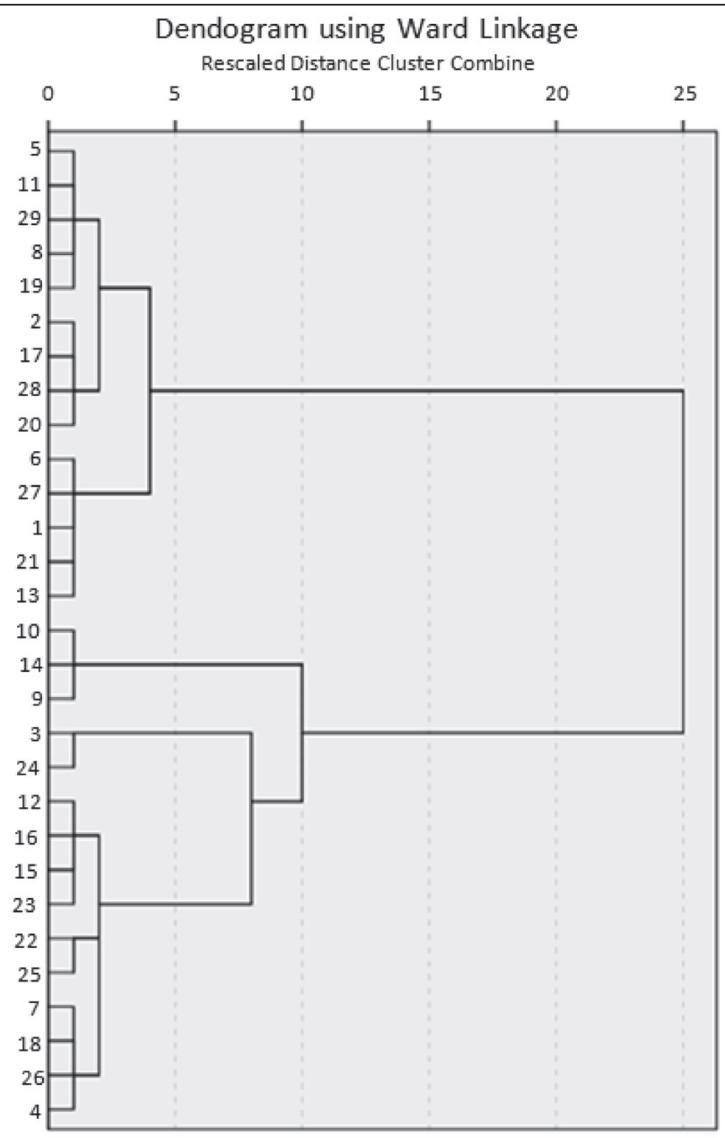


To sum it up, the only countries which have changed their cluster positions compared to 2010 are Italy and Poland. Italy moved from the fourth cluster in 2010 to the first cluster of countries with the highest GDP per capita in 2017. Poland also improved its position and moved from the cluster of countries with the lowest GDP per capita to the fourth cluster. The causes of the changes in these two countries are different. In the case of Italy, it was a decrease in the share of people employed in the primary sector and especially in the secondary sector and, conversely, an increase in the share of people employed in the tertiary and quaternary sectors. Italy moved from the fourth cluster to the first, economically strongest cluster despite the fact that its real GDP per capita even decreased slightly between 2010 and 2017. Poland moved from the second cluster in 2010, where it was together with Bulgaria and Romania, to the fourth cluster (which also includes, besides other countries, the other V4 countries) due to a decrease in the share of people employed in the primary sector and, conversely, its increase especially in the secondary and quaternary sectors. Its real GDP also increased between 2010 and 2017.

The average values of the share of people employed in individual sectors for the European Union as a whole as well as for each cluster individually, including GDP per capita within individual clusters, are shown in Tab. 3.

The average values of people employed in the individual sectors of the resulting clusters offer several conclusions.
The first cluster contains countries that acceded to the European Union before 2000, with the exception of Malta. These countries are now the economic engine of the European Union which, besides high GDP per capita, are also countries with a high level of innovation performance in the European Union. According to the European Innovation Scoreboard 2019, all countries in cluster 1 , with the exception of Malta and Italy, are innovation leaders or strong innovators. At the same time, only one country belonging to another cluster ranks amongst the countries with a higher level of innovation performance (Estonia). But Estonia, despite ranking amongst strong innovators in 2019, had a lower level of innovation performance than the countries in cluster 1 (again with the exception of Malta and Italy) (Hollanders et al., 2019).

The second cluster in 2017 has the same composition as the third cluster in 2010 and consists of coastal countries of Southern Europe (Spain, Cyprus, and Greece). These countries have an exceptionally high tertiary sector almost (and in the case of Cyprus above) $50 \%$. Conversely, in these three countries the level of employment in the secondary sector is especially in 2017 - significantly below the EU average. The dependence of these countries on tourism is very high and to some extent limits the ability of these countries to increase their innovation performance and potential of growth of GDP per capita otherwise than by a higher efficiency of tourism services. The consequence is also the fact that this group of countries was

Tab. 3: $\begin{aligned} & \text { Average values of variables for each cluster of the countries based on the } \\ & \text { sectoral division of the national economy and Real GDP per capita in } 2017\end{aligned}$

\begin{tabular}{l|c|c|c|c|c}
\multicolumn{1}{c|}{$\begin{array}{c}\text { Share } \\
\text { of countries }\end{array}$} & $\begin{array}{c}\text { Share } \\
\text { of people } \\
\text { of people } \\
\text { employed in } \\
\text { the primary } \\
\text { sector in } \%\end{array}$ & $\begin{array}{c}\text { Share } \\
\text { in the } \\
\text { secondary } \\
\text { sector in } \%\end{array}$ & $\begin{array}{c}\text { Share } \\
\text { of people } \\
\text { employed } \\
\text { in the tertiary } \\
\text { sector in } \%\end{array}$ & $\begin{array}{c}\text { employed } \\
\text { in the } \\
\text { quaternary } \\
\text { sector in } \%\end{array}$ & $\begin{array}{c}\text { Real gross } \\
\text { domestic } \\
\text { product per } \\
\text { capita in } €\end{array}$ \\
\hline $\begin{array}{l}\text { European Union }-28 \\
\text { countries }\end{array}$ & 4.7 & 21.4 & 38.1 & 35.8 & 27,780 \\
\hline First cluster & 2.58 & 18.92 & 36.94 & 41.55 & 40,355 \\
\hline Second cluster & 6.47 & 15.93 & 49.17 & 28.43 & 21,647 \\
\hline Third cluster & 21.85 & 26.75 & 32.55 & 18.85 & 7,315 \\
\hline Fourth cluster & 6.66 & 27.8 & 37.21 & 28.32 & 14,361 \\
\hline
\end{tabular}


the only one to achieve a lower real GDP per capita in 2017 than in 2010. It is also necessary to say that, although the level of GDP per capita in the countries of this cluster is only $53.64 \%$ of the average value of this indicator in cluster 1 , this level is still relatively high compared to the countries of the other two clusters.

In 2017, only Bulgaria and Romania remained in cluster 3 , whose composition and characteristics are similar to those of cluster 2 in 2010. In 2010, Poland was part of this cluster together with Bulgaria and Romania. Due to a decrease in the share of people employed in the primary sector and an increase in the share of people employed in the secondary and quaternary sectors, as well as due to the growth of GDP per capita between 2010 and 2017, Poland moved to cluster 4 in 2017. Bulgaria and Romania acceded to the European Union in 2007 and, as the only countries of the European Union, rank amongst the modest innovators (Hollanders et al., 2019). Both countries have the lowest GDP per capita in the European Union (less than $€ 10,000$ per capita in both 2010 and 2017). In terms of the share of people employed, the primary sector is very strong in both countries (with the highest share of people employed among all EU countries), while the share of people employed in the quaternary sector is the lowest of all EU countries in both 2010 and 2017.

Cluster 4 contains mainly countries that acceded to the EU after 2000, with the exception of Portugal, and in 2010 also with the exception of Italy. These are post-communist countries that have coped with the transition to a market economy relatively well, such as the V4 countries (with the exception of Poland in 2010), the Baltic countries, or the countries of the former Yugoslavia (Slovenia and Croatia) which are members of the EU. Despite their partial success in the transformation process, in most of these countries their GDP per capita levels were below or equal to $50 \%$ of the $\mathrm{EU}$ average for GDP per capita in both 2010 and 2017.

\subsection{Panel Regression Analysis}

The impact of individual sectors of the national economy on GDP (real) per capita of the Slovak Republic is examined through a panel regression analysis. In this analysis, the authors studied the period from 2001 to 2018 (with regards to the availability of data on GDP per capita in individual regions), using data for all 8 regions of the Slovak Republic. Our basic presumption that the economic structure is the fundamental cause of long-run growth is supported by many foreign empirical studies (Reinert, 2008; Stiglitz \& Greenwald, 2014). The input data of real GDP per capita in individual regions were obtained by adjusting the nominal GDP using the GDP price deflator based on data from the databases of the Statistical Office of the Slovak Republic "DATAcube". The input data of independent variables were absolute values of people employed in the given sectors of the national economy.

In addition, in the analysis, we decided to investigate a possible impact of time lags, which may have a significant impact on the relationship between the variables. It is likely that the sectoral division of the national economy in year $t$ is not reflected in GDP per capita in the same year, but only in year $t+1$.

In order to study causality between our variables we carried out Granger causality test. The results are shown in Tab. 4.

\begin{tabular}{l|c|c|c} 
Tab. 4: & $\begin{array}{c}\text { Results of Granger causality analysis between real GDP per capita and } \\
\text { the primary, secondary, tertiary and quaternary sectors of the national economy }\end{array}$ \\
\multicolumn{1}{c|}{ Null hypothesis } & Obs & F-statistic & Prob. \\
\hline PRIM(-1) does not Granger cause GDP & \multirow{2}{*}{120} & 0.24301 & 0.7847 \\
GDP does not Granger cause PRIM(-1) & & 8.73387 & 0.0003 \\
\hline SEC(-1) does not Granger cause GDP & \multirow{2}{*}{120} & 0.10623 & 0.8993 \\
GDP does not Granger cause SEC(-1) & \multirow{2}{*}{120} & 0.32856 & 0.7206 \\
\hline TERT(-1) does not Granger cause GDP & & 31.2906 & $1 . \mathrm{E}-11$ \\
GDP does not Granger cause TERT(-1) & \multirow{2}{*}{120} & 0.98078 & 0.3781 \\
\hline QUAT(-1) does not Granger cause GDP & & 11.6550 & $2 . \mathrm{E}-05$ \\
\hline GDP does not Granger cause QUAT(-1)
\end{tabular}


Based on the Granger causality tests, we can reject the hypothesis that GDP (real) per capita does not Granger cause individual national sectors (primary, secondary, tertiary, and quaternary). On the other hand, it seems that Granger causality runs one-way in all four cases from national sectors to GDP (real) per capita (at the $5 \%$ significance level). Based on these results it is appropriate to carry out a panel regression analysis examining a possible impact of the sectoral division of the national economy on GDP (real) per capita. Since there is a possibility of time lags on this impact, we have created two regression models including the impact of the primary, secondary, tertiary and quaternary sectors in time period $t$ as well as $t-1$ on GDP (real) per capita in time period $t$. The time lags were tested because the impact of the sectoral division of the national economy may not have an immediate impact on GDP (real) per capita. Based on the results of models (i.e. the model in time period $t$ and the model in time period $t-1$ ), specifically according to the level of Akaike info criterion, it is obvious that the model with a time lag of 1 year (i.e. model $t-1$ ), shown in Tab. 5 , is more suitable.

Based on the research goals and the research sample the fixed effects model of cross-sectional data was used in the further analysis.

The panel regression model examined the impact of the sectoral division of the national economy of the Slovak Republic in period $t$ on GDP (real) per capita in period $t+1$. Based on the results of the model, the changes in the given sectors (primary, secondary, tertiary and quaternary) explain $97.08 \%$ of changes in GDP (real) per capita. The regression line of the given impact can be defined as follows:

$$
\begin{aligned}
& \hat{y}=2.1346-0.3643 \text { prim }-0.2504 \mathrm{sec}+ \\
& \quad+0.6742 \text { tert }+0.2862 \text { quat }
\end{aligned}
$$

where prim represents the primary sector, sec represents the secondary sector, tert represents the tertiary sector, and quat represents the

\section{Results of panel regression models examining the impact of the sectoral Tab. 5: division of the national economy of the Slovak Republic on real GDP per capita in the individual regions}

Dependent Variable: GDP_R

Method: Panel Least Squares

Sample (adjusted): 20022018

Period included: 17

Cross-sections included: 8

Total panel (balanced) observations: 136

\begin{tabular}{l|c|c|c|c}
\hline \multicolumn{1}{c|}{ Variable } & Coefficient & Std. error & T-statistic & Prob. \\
\hline C & 2.134624 & 0.566038 & 3.771233 & 0.0003 \\
\hline PRIM(-1) & -0.364330 & 0.034828 & -10.46077 & 0.0000 \\
\hline SEC(-1) & -0.250359 & 0.089360 & -2.801697 & 0.0059 \\
\hline TERT(-1) & 0.674230 & 0.086369 & 7.806395 & 0.0000 \\
\hline QUAT(-1) & 0.286204 & 0.042851 & 6.679080 & 0.0000 \\
\hline
\end{tabular}

\begin{tabular}{l|c|l|c}
\hline \multicolumn{4}{c}{ Effects specification } \\
\hline Cross-section fixed (dummy variables) & \multicolumn{3}{l}{0.067294} \\
\hline R-squared & 0.973212 & Mean dependent var & 0.188633 \\
\hline Adjusted R-squared & 0.970836 & S. D. dependent var & -3.948750 \\
\hline S. E. of regression & 0.032214 & Akaike info criterion & -3.691751 \\
\hline Sum squared resid. & 0.128678 & Schwarz criterion & -3.844312 \\
\hline Log likelihood & 280.5150 & Hannan-Quinn criter. & 1.502942 \\
\hline F-statistic & 409.5440 & Durbin-Watson stat & \\
\hline Prob(F-statistic) & 0.000000 & & \\
\hline
\end{tabular}


quaternary sector. Based on the prob (f-statistic) of the model as a whole we see that model is statistically significant. Similarly, based on the prob statistic of given sectors (prim, sec, tert, quat) in period $t-1$ we can suggest that all four sectors have a significant impact on GDP (real) per capita in period $t$. Since the Durbin-Watson statistic is greater than adjusted R-squared, we did not see the presence of autocorrelation at lag 1 in the residuals. In more detail, according to Durbin-Watson significance tables (Savin \& White, 1977), when we have sample size 136 and 4 regressors, in order not to reject the null hypothesis of non-autocorrelated errors, the Durbin-Watson statistic should be between bounds dl: 1.482 and dU: 1.604 . According to our results, we do not reject the null hypothesis.

Therefore, we can interpret the impact of all four sectors of the national economy on GDP (real) per capita. The results of the model suggest that the primary sector has a negative impact, specifically a $1 \%$ decrease in people employed in the primary sector causes a $0.36 \%$ increase in GDP (real) per capita. Similarly, a 1\% decrease in people employed in the secondary sector causes a $0.25 \%$ increase in GDP (real) per capita. These results are in accordance with the elementary analysis of sectors in other EU countries. Precisely, the shares of the primary and secondary sectors are decreasing over time in all EU countries in general. However, in the countries where this decrease is faster, GDP per capita is usually above average. According to Turečková (2012), it is typical for the primary sector that it has a larger share of people employed than its share of GDP. Hudcovský (2013) states that the share of the secondary sector is decreasing over time. According to our cluster analysis we can say that the higher the share of people employed in the primary and secondary sectors, the lower GDP per capita. Based on these results, potentially, the primary and secondary sectors should have a negative impact on GDP per capita, since employment in the primary and secondary sectors is significant in those regions of the country or in those countries that are the least developed ones.

On the other hand, the employment in the tertiary and quaternary sectors has a positive impact on GDP (real) per capita. Specifically, in Slovakia, the tertiary sector has a greater impact, where a $1 \%$ increase in employment causes a $0.67 \%$ increase in GDP (real) per capita. A $1 \%$ increase in employment in the quaternary sector causes a $0.29 \%$ increase in GDP (real) per capita. Our results are basically in line with theoretical knowledge as well as with results in other EU countries. While the impact of the quaternary sector is definite, the impact of the tertiary sector is not so clear. Turečková (2014) agrees that the quaternary sector is a source of national and regional competitiveness. Our cluster analysis indicates that countries with the highest average share of people employed in the quaternary sector have the highest GDP per capita on average.

\section{Conclusions}

The role and importance of sectors for the national economy have changed over time. The number of people employed in individual sectors has changed, too. Ultimately, these changes have also had a significant impact, whether positive or negative, on GDP per capita. The main objective of this work was to examine the impact of the sectoral division of the national economy on a country's GDP per capita. Our research was based on cluster analysis of EU countries and then more closely focused on Slovakia through the panel regression analysis and the Granger causality tests on a sample of all 8 self-governing regions for the period 2001-2018.

In all European Union countries, most people were employed in the tertiary or quaternary sector in 2010 a 2017, with two exceptions. In 2010, in Romania the highest share of people was employed in the primary sector (33.24\%), and in 2017, in the Czech Republic the highest share of people was employed in the secondary sector $(36.0 \%)$. Based on the data of sectoral employment in the European Union countries and their GDP per capita, four clusters were created having similar properties in the indicators investigated by us in both years considered. In both years, the first cluster clusters together the most competitive and innovative countries of the European Union. These countries have their GDP per capita significantly higher than the EU average, and at the same time the share of people employed in the quaternary sector is the most dominant among other EU countries.

In 2010, the second cluster (it is the third cluster in the dendrogram for 2017) consists only of Poland Romania, and Bulgaria. In 2017, Poland moved to the fourth cluster, which consists of countries with higher economic and 
innovation performance. Bulgaria and Romania are countries with a very strong primary sector and a weaker quaternary sector in terms of employment, a low level of GDP per capita, and a low level of innovation performance.

The third cluster (in 2010), which is also the second cluster in the dendrogram for 2017 , consists of coastal countries of Southern Europe with particularly strong tertiary sectors, benefiting mainly from tourism. The share of people employed in the tertiary sector is approx. $50 \%$ in this cluster.

The fourth cluster consists predominantly (but not only) of the transitional countries that acceded to the EU in 2004. The countries in this cluster are generally characterised by a relatively high share of people employed in the secondary sector and a lower share of people employed in the quaternary sector compared to the average share of these sectors in the EU. At the same time, they have a below-average level of GDP per capita and a lower level of innovation performance than the EU average.

A closer examination of development of sectoral division of Slovakia over time shows that the share of people employed in the primary sector has dramatically decreased over the past 70 years (from $62 \%$ in 1948 to $3 \%$ in 2018). In 1993, the number of people employed in the tertiary sector exceeded the number of people employed in the secondary sector in Slovakia for the first time. Over the past five years, the number of people employed in the quaternary sector has also significantly approached the number of people employed in the secondary sector in Slovakia.

The results of Granger causality prove that the causality between sectoral division and real GDP per capita run one way in all four cases, from national sectors to GDP per capita. Panel regression analysis then identified a significant impact of employment levels in all four sectors of the national economy on GDP per capita. The model results suggest that a $1 \%$ decrease in the number of people employed in the primary sector causes a $0.36 \%$ increase in real GDP per capita. Similarly, a 1\% decrease in the number of people employed in the secondary sector causes a $0.25 \%$ increase in real GDP per capita. Conversely, an increase in employment levels in the tertiary and quaternary sectors has a positive impact on real GDP per capita. Specifically, in Slovakia, the tertiary sector has a greater impact, with a $1 \%$ increase in the number of employees causing a $0.67 \%$ increase in GDP (per capita). A 1\% increase in employment in the quaternary sector causes a $0.29 \%$ increase in (real) GDP. The results achieved are in line with theoretical knowledge as well as with results in other EU countries. In particular, the impact of an increase in the number of people employed in the quaternary sector on the growth of GDP per capita is in line with both empirical observations of the most competitive and innovative EU countries and literature dealing with this issue (Marjanović, 2010; Segal, 2011; Melachroinos \& Spence, 2013; Cooke et al., 2019).

The partial aim of our study was to provide evidence that the quaternary sector has a positive effect on the national economy of the given country. A presumption was made based on the wide body of empirical literature and was partially confirmed by the cluster analysis, where a relationship between a high share of people employed in the quaternary sector and the national economy's GDP can be observed. In other words, countries which are considered to be the innovation leaders of the EU are at the same time capable of transforming that knowledge into economic performance expressed by GDP per capita. However, the effect of the quaternary sector on a country where the majority of population is employed in the secondary and tertiary sectors, like Slovakia, had been questionable. The answer was provided by the panel regression analysis, whereas based on the results it is clear that development and support of the quaternary sector will have a positive impact on the real GDP. Economic activities and operations included in the quaternary sector are like an engine of innovations. They create space for the emergence of new markets and branches and are reflected in the original work and management, practices and methods. Moreover, that kind of innovation and knowledge-based growth should not cause or be easily suppressed by conditions like depleted resources, pollution and crowding.

Therefore, the quaternary sector is important for current and future economic sustainable growth and qualitative development of the national economy and society. However, it is important to note that the quaternary sector and its growing share in the overall sectoral structure of the economy increasingly requires a highly skilled and educated workforce. Its 
high representation in the most developed countries is an important trend in the future, too. At the same time, we can expect an even higher share and more dynamic development of the quaternary sector in developed regions and countries in the future. These conclusions provide valuable information for economic policy makers in the optimum targeting of state aid. It is obvious that support for education, skills, and human capital which is focused secondarily on the development of the quaternary sector has the potential to ensure sustainable and dynamic economic growth of a country in the long term.

\section{References}

Abonyi, J., \& Feil, B. (2007). Cluster Analysis for Data Mining and System Identification. Birkhäuser Basel: Springer Science \& Business Media. https://doi.org/10.1007/978-3-76437988-9

Andreoni, A. (2014). Structural learning: Embedding discoveries and the dynamics of production. Structural Change and Economic Dynamics, 29(2), 58-74. https://doi. org/10.1016/j.strueco.2013.09.003

Andreoni A., \& Scazzieri, R. (2014). Triggers of change: Structural trajectories and production dynamics. Cambridge Journal of Economics, 38(6), 1391-1408. https://doi. org/10.1093/cje/bet034

Bell, D. (1976). Welcome to the postindustrial society. Physics Today, 29(2), 46-49. https://doi.org/10.1063/1.3023314

Clark, T. S., \& Linzer, D. A. (2015). Should I Use Fixed or Random Effects? Political Science Research and Methods, 3(2), 399-408. https://doi.org/10.1017/psrm.2014.32

Constantine, C. (2017). Economic structures, institutions and economic performance. Economic Structures, 6(2), 1-18. https://doi.org/10.1186/s40008-017-0063-1

Cooke, P., Yun, J. H. J., Zhao, X. F., \& Kim, Y. D. (2019). The digital, quaternary or 4.0 web economy: aspects, effects and implications. International Journal of Knowledge-Based Development, 10(3), 193-212. https://doi. org/10.1504/IJKBD.2019.103201

European Communities. (2008). NACE Rev. 2: Statistical classification of economic activities in the European Community. Luxembourg: European Commission.

Eurostat. (2019a). National accounts employment data by industry. Retrieved November 25, 2019, from https://appsso. eurostat.ec.europa.eu/nui/show.do?dataset =nama_10_a64_e\&lang=en

Eurostat. (2019b). Real GDP per capita. Retrieved November 25, 2019, from https://ec.europa.eu/eurostat/databrowser/ view/sdg_08_10/default/table?lang=en

Feldstein, M. (2017). Underestimating the Real Growth of GDP, Personal Income, and Productivity. Journal of Economic Perspectives, 31(2), 145-164. https://doi.org/10.1257/ jep.31.2.145

Fourastié, J. (1951). Le Grand espoir du XXe Siecle: Progres technique, Progres Economique, Progres Social. Political Science Quarterly, 66(4), 603-606.

Granger, C. W. J. (1969). Investigateing Causal Relations by Econometric Models and Cross-spectral Methods. Econometrica, 37(3), 424-438. https://doi.org/10.2307/1912791

Green, B. F., \& Tukey, J. W. (1960). Complex analyses of variance: General problems. Psychometrika, 25, 127-152. https://doi.org/10.1007/BF02288577

Hedvičáková, M., \& Král, M. (2019). Benefits of KPIs for Industry Sector Evaluation: The Case Study from the Czech Republic. E\&M Economics and Management, 22(2), 97-113. https://doi.org/10.15240/tul/001/2019-2-007

Hollanders, H., Es-Sadki, N., \& Merkelbach, I. (2019). European Innovation Scoreboard 2019. Luxembourg: Publications Office of the European Union.

Hudcovský, M. (2013). Pracovná náročnost' ekonomického rastu regiónu V4 a vybraných západných krajín. Bratislava: Ekonomický ústav SAV.

Kenessey, Z. (1987). The Primary, Secondary, Tertiary and Quaternary Sectors of the Economy. The Review of Income and Wealth, 33(4), 359-385. https://doi. org/10.1111/j.1475-4991.1987.tb00680.x

Korec, P. (2007). Vplyv post-industriálneho štádia vývoja spoločnosti a globalizácie na regionálny vývoj Slovenska. Geographia Cassoviensis, 1(1), 75-80.

Mateides, A., \& Ďad'o, J. (2002). Služby teória služieb, marketing služieb. Bratislava: Epos.

Marjanović, V. (2010). Significance and Influence of Economic Structure on Economic Development. Economic Themes, 48(3), 369-382.

Melachroinos, K. A., \& Spence, N. (2013). The Territorial Impact of the Knowledge Economy: Intangibles and Regional Inequality 
in Great Britain. European Planning Studies, 21(10), 1491-1508. https://doi.org/10.1080/09 654313.2012.722951

Melišek, F. (2008). Ekonomický rast a štruktúrne zmeny. Bratislava: Sprint dva.

Mička, V., Čáp, V., \& Bondyová, J. (1985). Historická statistická ročenka ČSSR. Prague: SNTL.

Reinert, E. (2008). How rich countries got rich and why poor countries stay poor. New York, NY: Public Affairs.

Savin, N. E., \& White, K. J. (1977). The Durbin-Watsin Test for Serial Correlation with Extreme Sample Sizes or Many Regressors. Econometrica, 45(8), 1989-1996. https://doi. org/10.2307/1914122

Segal, Q. (2011). Cambridge Cluster at 50 - The Cambridge Economy: Retrospect and Prospect (Final report to EEDA and partners). Wicksteed, UK.

SLOV-LEX. (2007). Vyhláška Štatistického úradu Slovenskej republiky z 18. júna 2007, ktorou sa vydáva Štatistická klasifikácia ekonomických činností. Retrieved October 7, 2019, from https://www.slov-lex.sk/pravnepredpisy/SK/ZZ/2007/306

Statistical Office of the Slovak Republic. (1991-2008). Statistical Yearbook of the Slovak Republic. Bratislava: VEDA, Publishing House of the Slovak Academy of Sciences.

Stehel, V., Horák, J., \& Vochozka, M. (2019). Prediction of Institutional Sector Development and Analysis of Enterprises Active in Agriculture. E\&M Economics and Management, 22(4), 103-118. https://doi.org/10.15240/tul/001/2019-4-007
Stiglitz, J. E., \& Greenwald, B. C. (2014). Creating a Learning Society: A New Approach to Growth, Development, and Social Progress. New York, NY: Columbia University Press.

Turečková, K. (2012). Vymezení sektorové struktury hospodářství $v$ kontextu formování znalostní ekonomiky. In Sborník príspěvků V. Mezinárodní vědecké konference doktorandů a mladých vědeckých pracovníků [Proceedings from the V. International Scientific Conference for Ph.D. Students and Young Scientists] (pp. 651-657). Karviná: Silesian University in Opava, School of Business Administration in Karviná.

Turečková, K. (2014). Quaternary sector as a source of growth and competitiveness in the EU. In Proceedings of the 2nd International Conference on European Integration (pp. 723-730). Ostrava: VSB - Technical University of Ostrava.

Turečková, K., \& Martinát, S. (2015). Quaternary sector and extended sectoral structure of the economy in the selected European countries (Working Paper in Interdisciplinary Economics and Business Research no. 10). Karviná: Silesian University in Opava, School of Business Administration in Karviná.

Yun, J. H. J. (2015). How do we conquer the growth limits of capitalism? Schumpeterian Dynamics of Open Innovation. Journal of Open Innovation: Technology, Market, and Complexity, 1(2), 17, https://doi.org/10.1186/ s40852-015-0019-3 